\title{
Freedom fighter
}

\section{To reclaim the planet.}

\section{rpg}

The stars are veiled tonight, as if ashamed at their unwitting collusion. Streetlights remain unlit, not a lamp shines from a single window.

It is the hour of curfew. I creep along the back streets, through alleys, behind gardens and beside fences. My eyes are accustomed now; what little glow comes from the military compounds and searchlights reflecting from the low clouds is sufficient. Besides, I know these roads, this town. I grew up here.

We had received their radio signals two years before; spent months deciphering them, translating their language, composing replies. Their spaceships, as big as cities, hovered far above our farms and valleys with gunports closed. When their Marines came down, in house-sized metal boxes atop tongues of fire, they wore soft caps instead of helmets, their weapons shouldered and pointing at the sky.

They said they were our friends. We welcomed them. The President had been briefed and re-briefed until her every word, every breath, was perfect.

There is a rumble in the distance. A patrol is approaching. It is a couple of streets away, and their lights shutter them into a narrow cone of blindness. I am safe, for now.

I have made it to the rendezvous. I roll up a sleeve to display the Mark, which glows with a faint phosphorescence, and wait.

Superficially they resemble us. Bilaterally symmetrical, but shorter and stockier; evolution responding to the immense gravity of their home planet to stunt them grotesquely. Their limbs - as in all but one of their native animals - are shortened out of all proportion. Their sensory organs, clustered tightly as they are, caused a number of dignitaries to feel physically sick. Some theologians wondered how they could be made in the image of the same God. The smarter ones talked ceaselessly about internals: how they must have souls and intelligence, and how love and justice were to be considered attributes of God more than mere physical form.

The President met them with grace and dignity, extended an arm in (what we hoped was) a universal gesture of peace. It seemed to please, and possibly amuse, them.

A soft hand extends from the shadows, clasps mine.

"I didn't think you'd make it. The patrols have been everywhere."

"Beloved. You forget how well I know this place." I try to look into her eyes, but all I can see is the Mark on her own arm.

"Did you bring the detonator?"

"Of course," I say. "Is - "

"Yes. He is waiting for us. We must go now."

The aliens brought with them technology and medicine. With them came their government, their philosophies, their missionaries and religion. It did not take

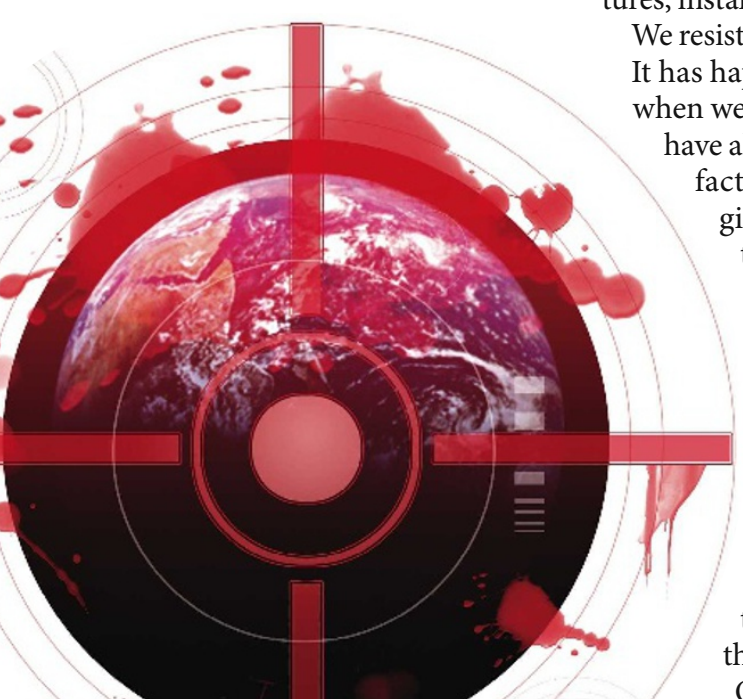

up. We surrendered without a fight, asked only that we be left in peace, to return to how we were before they arrived.

She kisses me.

"If I get back —"

"When," I say gently, "When you get back, my angel. We have sympathizers, remember? They will help you escape."

Then the rumours started. That we had our own interstellar programme. That we had our own weapons of equal destructive force.

The invasion, in the name of 'galactic security', was swift, unambiguous and brutal. They dismantled our executive structures, installed a puppet government.

We resisted of course.

It has happened before on our planet, $₫$ en we still had parochial rulers. We ave always had trouble with certain factions - the immoderate religious, the malcontent, the seditious, those who felt that the resources and the power had been unfairly distributed. In our own troubled history, major powers have frequently tried to project their influence around the globe, to protect their interests or to displace inconvenient governments, to convert people to their own way of thinking through military might.

Once they even called it 'liberation', but the resistance of ordinary people, fighting for what they knew and loved, escalated into a conflagration that almost consumed our entire civilization. We stepped back from the brink, vowed never to let it happen again.

long for some disaffected individuals, fearful for our way of life, to hijack a returning transport and crash it into one of the eight ring supports being built on their planet. The President, as soon as she heard, boarded the next transport unescorted and unprotected, to plead forgiveness.

They arrested her. Put her in jail, sent us videotapes of her trial.

Executed her for the sins of a few renegades.

There would have been war, but we were completely out-classed. We saw the awful destructive power of their weapons, tested on infertile and uninhabited desert: weapons that we learned had been used without a second thought on their own kind. The supply of technology and medicines dried
"Will you wait for me?" she says softly.

"Of course. There is nothing else I can do." I touch her face in goodbye. I feel her breath on my hand. Then she is gone, lost to the night.

They came from the stars. And now she boards this sleek and urgent vessel, her mission as terrible as its cargo: to visit upon the planet they call 'Earth' the destruction they would wage upon us. rpg is a molecular cell biologist at the University of Sydney. He writes semifiction at http://network.nature.com/ blogs/user/rpg and http://blogs.usyd. edu.au/labrats. 